\title{
Concentration of Copper 63 by the Countercurrent Electromigration Method
}

\author{
By Samuel L. Madorsky and Sidney Straus
}

\begin{abstract}
Concentration of ${ }^{63} \mathrm{Cu}$ by the countercurrent electromigration method is described. The electromigration cell was operated with cupric sulfate as the electrolyte for periods of about 400 to 500 hours. A definite, though small, concentration of ${ }^{63} \mathrm{Cu}$ in the cathode compartment of the cell was obtained. The terminal separation coefficient was about onethird as large as that found for chlorine under similar conditions.
\end{abstract}

\section{Introduction}

Concentration of isotopes by the countercurrent electromigration method was carried out successfully in the case of singly charged ions such as $\mathrm{K}^{+1}$ and $\mathrm{Cl}^{-}{ }^{2}$ It was of interest to find out whether a doubly charged isotopic ion could be concentrated by this method. The cupric ion $\mathrm{Cu}^{++}$was selected for this purpose, because it is the lightest element that forms doubly charged ions in aqueous solution and which at the same time exists in nature as a mixture of only two isotopic species.

\section{Arrangement of the Electromigration Cell}

Ordinary copper consists of a mixture of two stable isotopes ${ }^{63} \mathrm{Cu}$ and ${ }^{65} \mathrm{Cu}$ in the ratio $R_{0}=$ ${ }^{63} \mathrm{Cu} /{ }^{65} \mathrm{Cu}=2.2192$. The electromigration cell can be so arranged that the flow of liquid in the packed column is in a direction from the cathode to the anode, i. e., in a direction opposite to that of the movement of the $\mathrm{Cu}^{++}$ions. When the cell operates under controlled conditions so that the concentration of the electrolyte stays constant, the velocity of the liquid counterflow is smaller than the velocity of ${ }^{63} \mathrm{Cu}^{++}$. Thus the ${ }^{63} \mathrm{Cu}^{++}$ moves into the cathode compartment, while ${ }^{65} \mathrm{Cu}$ is forced back toward the anode.

The electrolyte consisted of a solution of chemi-

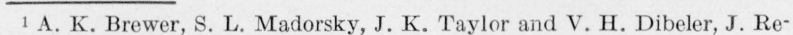
search NBS 38, 137 (1947) RP1765.

2 S. L. Madorsky and S. Straus, J. Research NBS 38, 185 (1947) RP1767. cally pure grade $\mathrm{CuSO}_{4}$ in the ratio of one equivalent of $\mathrm{CuSO}_{4}$ to 60 moles of $\mathrm{H}_{2} \mathrm{O}$. The operation of the cathode was controlled by means of a boundary between the cupric sulfate solution and a solution of sulfuric acid. The cathode will be under proper control as long as the boundary remains sharp and stationary. This condition is satisfied when the concentration $\mathrm{C}_{1}$ of the $\mathrm{H}_{2} \mathrm{SO}_{4}$ solution is related to the concentration $\mathrm{C}_{2}$ of the $\mathrm{CuSO}_{4}$ solution in the following manner: $\mathrm{C}_{1} / \mathrm{C}_{2}=T_{\mathrm{H}^{+}} / T_{\mathrm{Cu}^{++}}$, where $T_{\mathrm{H}^{+}}$and $T_{\mathrm{Cu}^{++}}$are the transport numbers of $\mathrm{H}^{+}$and $\mathrm{Cu}^{++}$ions, respectively. It was found experimentally that a solution of $\mathrm{H}_{2} \mathrm{SO}_{4}$ containing 1 equivalent of $\mathrm{H}_{2} \mathrm{SO}_{4}$ to 24 moles of $\mathrm{H}_{2} \mathrm{O}$, in contact with 1:60 $\mathrm{CuSO}_{4}$ solution gave a sharp and steady boundary .

The cathode itself consisted of a platinum gauze about $4 \mathrm{~cm}^{2}$ in area immersed in the acid. The reactions taking place on the acid side of the boundary are $2 \mathrm{H}^{+}+2 e=\mathrm{H}_{2} ; \mathrm{SO}_{4}^{--}$moves out across the boundary in the direction of the anode. In order to maintain constant conditions in the cathode compartment, it was flushed with a continuous stream of the $1: 24 \mathrm{H}_{2} \mathrm{SO}_{4}$ solution.

The anode consisted of a copper rod $3 / 4 \mathrm{in}$. in diameter. The anode reaction can be expressed by the equation

$$
\mathrm{SO}_{4}^{--}+\mathrm{Cu}=\mathrm{CuSO}_{4}+2 e .
$$

An amount of water, equal to 36 moles per Faraday, was added in the neighborhood of the copper rod and the solution agitated by means of an air- 
bubbler. This amount of water, required to maintain the concentration of $\mathrm{CuSO}_{4}$ in the anode compartment, was calculated on the basis of the transport numbers of $\mathrm{Cu}^{++}$and $\mathrm{SO}_{4}^{--}$in the electrolyte, which are approximately 40 and 60 respectively. Since the increase in the concentration of $\mathrm{CuSO}_{4}$ around the anode is governed primarily by the inflow of $\mathrm{SO}_{4}^{--}$into the anode compartment, the amount of water required to bring the 1:60 $\mathrm{CuSO}_{4}$ solution back to its original concentration is $60 \times 0.60=36$ moles of $\mathrm{H}_{2} \mathrm{O}$ per Faraday. As an additional precaution, the anode compartment was flushed with a stream of 1:60 $\mathrm{CuSO}_{4}$. The method of metering the restituent liquids has been described in previous papers (see footnotes 1 and 2).

Characteristic details of the solutions employed are given in table 1. As seen from this table the $1: 24 \mathrm{H}_{2} \mathrm{SO}_{4}$ solution has a lower density than the 1:60 $\mathrm{CuSO}_{4}$ and therefore forms the upper layer at the boundary.

TABLE 1. Solutions employed in the copper electromigration experiments

\begin{tabular}{|c|c|c|c|c|}
\hline Solution & $\begin{array}{c}\text { Ratio- } \\
\text { solute: } \\
\mathrm{H}_{2} \mathrm{O}\end{array}$ & $\begin{array}{c}\text { Concen- } \\
\text { tration }\end{array}$ & $\begin{array}{c}\text { Density } \\
\text { at } 20^{\circ} \mathrm{C}\end{array}$ & Normality \\
\cline { 2 - 4 } & & & & \\
$\mathrm{CuSO}_{4}$ & $1: 60$ & $\begin{array}{c}\text { Percent } \\
\mathrm{H}_{2} \mathrm{SO}_{4} \ldots .88\end{array}$ & 1.0715 & 0.9230 \\
& $1: 24$ & 10.17 & 1.0672 & 2.2131 \\
\hline
\end{tabular}

The electromigration cell and details of the electrodes are shown diagrammatically in figure 1. The cell is similar to the one that was used in concentrating ${ }^{35} \mathrm{Cl}$ (see footnote 2), except for the following minor differences: (a) The cell electrolyte here is below the boundary instead of above it as in the chlorine cell. (b) Instead of a circular cross-section tube with an internal water-cooler in the boundary region, a flattened tube without a water-cooler was used here. The cross sectional dimensions of the tube inside were $1 \mathrm{~cm}$ by $2 \mathrm{~cm}$. This way of cooling the boundary region was found to be more satisfactory than by using a watercooler. (c) Glass wool between the outer and inner cups of the cathode compartment, also, at the upper end of the flat tube served here to protect the boundary from disturbances caused by the addition of the acid.

Operation of the cell was automatic and continuous, requiring very little attention. Altögether five experiments, lasting from 380 to 525 hr of continuous operation, were carried out. In all experiments the current was 200 ma. The cell was kept in a constant temperature bath maintained at $29^{\circ} \pm 0.1^{\circ}$ C. Samples of overflow liquid from the cathode and anode compartments were analyzed at intervals for $\mathrm{H}_{2} \mathrm{SO}_{4}$ and $\mathrm{CuSO}_{4}$ content, respectively. The results of these analyses are given in table 2. The cathode overflow liquid was tested also for copper with negative results. The boundary could be observed readily

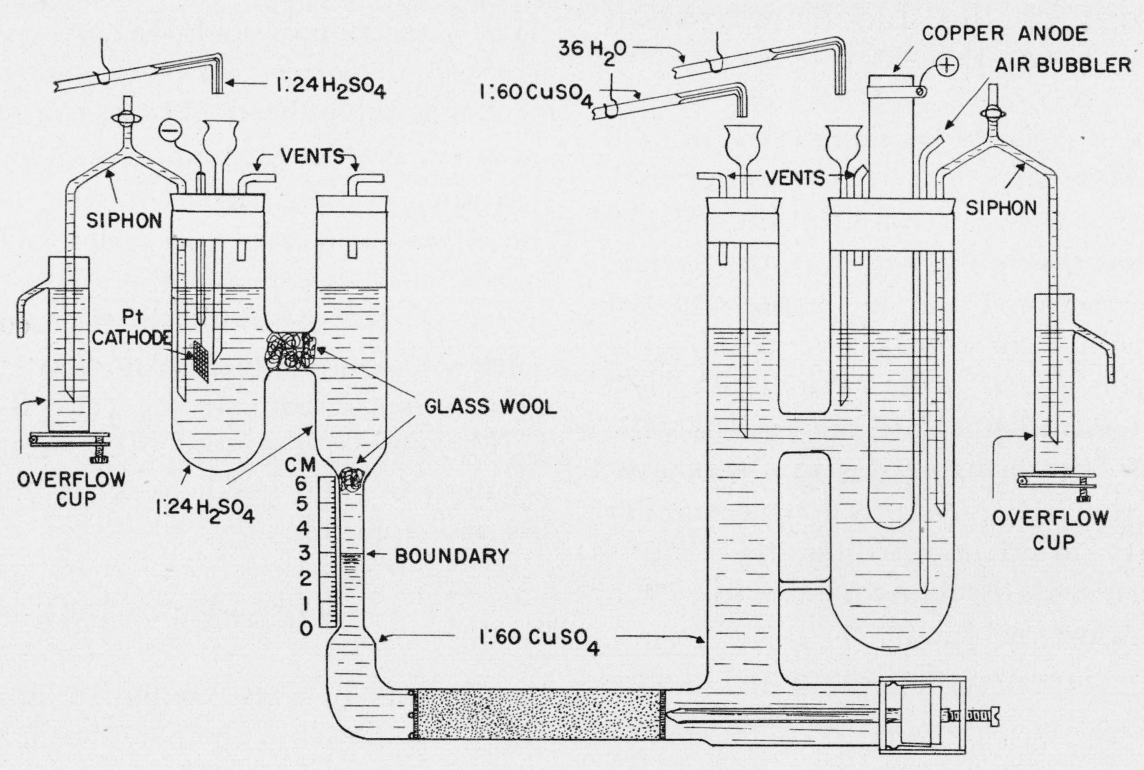

FIgURE 1. Electromigration cell used in concentrating ${ }^{63} \mathrm{Cu}$ 
because of the blue color of the cupric sulphate solution. It moved slowly up or down during the experiments within a range of about $2 \mathrm{~cm}$. A slight variation of the position of the boundary merely means that some of the liquid containing the ${ }^{63} \mathrm{Cu}$ concentrate fluctuates in and out of the packing. At the end of each experiment the content of the cathode compartment between the boundary and the packing was removed by means of a pipette inserted below the boundary while the current was on. It was not possible during the drawing of the sample to prevent some of the acid above the boundary and some of the electrolyte from the cathode end of the packing from mixing with the main body of the ${ }^{63} \mathrm{Cu}$ concentrate.

TABLE 2. Analysis of cathode and anode overflow liquids

\begin{tabular}{|c|c|c|c|}
\hline Experiment & $\begin{array}{l}\text { Hours } \\
\text { after } \\
\text { start }\end{array}$ & $\begin{array}{l}\text { Percentage } \\
\text { of } \mathrm{H}_{2} \mathrm{SO}_{4} \\
\text { in cathode } \\
\text { overflow }\end{array}$ & $\begin{array}{l}\text { Percentage } \\
\text { of CuSO } \\
\text { in anode } \\
\text { overflow }\end{array}$ \\
\hline \multirow{8}{*}{$1 \ldots$} & 0 & 10.17 & 6.88 \\
\hline & 16 & (.......... & 7. 57 \\
\hline & 44 & 10.92 & 7.55 \\
\hline & 117 & 11.17 & 7. 53 \\
\hline & 165 & 10.93 & 7. 47 \\
\hline & 333 & 9.80 & 7. 30 \\
\hline & 453 & 9. 80 & 7. 17 \\
\hline & $\int \begin{array}{r}94 \\
10\end{array}$ & 10.10 & 8. 10 \\
\hline \multirow{6}{*}{$\begin{array}{l}4 \\
5\end{array}$} & $\left\{\begin{array}{l}149 \\
238\end{array}\right.$ & 9.84 & 8. 21 \\
\hline & 382 & 976 & $\begin{array}{l}7.27 \\
7.39\end{array}$ \\
\hline & $\int 68$ & 9. 95 & 7. 70 \\
\hline & $\{212$ & 9. 85 & 6.85 \\
\hline & 357 & 9. 94 & 7.15 \\
\hline & 288 & 10. 17 & 7.03 \\
\hline
\end{tabular}

A knowledge of the cathode volume is necessary, as will be shown later, for the calculation of the separation coefficient involved in the concentration of ${ }^{63} \mathrm{Cu}$ by the electromigration method. This volume was calculated in the following manner. The liquid drawn from the cathode compartment was evaporated to dryness and the residue weighed as $\mathrm{CuSO}_{4} \cdot 5 \mathrm{H}_{2} \mathrm{O}$. The volume of solution having a concentration of 6.88-percent $\mathrm{CuSO}_{4}$ and corresponding to the total $\mathrm{CuSO}_{4}$. $5 \mathrm{H}_{2} \mathrm{O}$ in the cathode sample could then be calculated. This volume was taken as the cathode volume and is shown in table 3 .

\section{Mass-Spectrometer Analysis of Ratios ${ }^{63} \mathrm{Cu} /{ }^{65} \mathrm{Cu}$}

Samples of $\mathrm{CuSO}_{4}$ removed from the cathode compartment, as well as samples of ordinary $\mathrm{CuSO}_{4}$, were converted into anhydrous $\mathrm{CuCl}$ and
TaBle 3. Some experimental details of the copper electromigration experiments

\begin{tabular}{|c|c|c|}
\hline Experiment & Time & $\begin{array}{l}\text { Cathode } \\
\text { volume }\end{array}$ \\
\hline 1 & $\begin{array}{l}h r \\
525\end{array}$ & $\begin{array}{c}m l \\
26\end{array}$ \\
\hline $2 \ldots$ & 432 & 24 \\
\hline $3 \ldots$ & 380 & 33 \\
\hline $4 \ldots$ & 429 & 27 \\
\hline $5 \ldots$ & 487 & 27 \\
\hline
\end{tabular}

used in this form in the analysis of ratio ${ }^{63} \mathrm{Cu} /{ }^{65} \mathrm{Cu}$ in the mass spectrometer. The conversion was carried out in two steps. In the first step, $\mathrm{CuSO}_{4}$ was converted into $\mathrm{Cu}_{2} \mathrm{O}$ by the wellknown method of heating an aqueous solution of $\mathrm{CuSO}_{4}$ in the presence of glucose, Rochelle salt, and sodium hydroxide. The bright-red precipitate formed was washed alternately with water and alcohol and then dried. In the second step, the $\mathrm{Cu}_{2} \mathrm{O}$ was heated at $80^{\circ} \mathrm{C}$ in a stream of dry gaseous $\mathrm{HCl}$. The resulting anhydrous $\mathrm{CuCl}$ was cooled in a stream of dry nitrogen and sealed in a glass tube.

The mass-spectrometer analyses were carried out by A. E. Cameron and J. R. White in the Tennessee Eastman Laboratory at Oak Ridge, Tenn. Four series of analyses were made. The results are shown in table 4 . Ratios of ${ }^{63} \mathrm{Cu} /{ }^{65} \mathrm{Cu}$ in ordinary copper and in the enriched cathode samples are designated as $R_{0}$ and $R_{t}$ respectively, where $t$ stands for total time of operation of the cell in hours. In table 4 the $R_{0}$ values, except those marked with an asterisk, represent averages of two $R_{0}$ values obtained before and after the corresponding $R_{t}$ values. This table also shows enrichment of ${ }^{63} \mathrm{Cu}$ as $R_{t} / R_{0}$ for any given cathode sample.

The separation coefficient $(\epsilon-1)$ can be calculated by means of a formula derived in a previous paper (see footnote 1) on electromigration. In the case of concentration of copper isotopes, this formula can be put in the simple form

$$
\epsilon-1=0.3352 \frac{V_{c} C\left(R_{t}-R_{0}\right)}{N_{1} N_{2} t\left(R_{t}+1\right)\left(R_{0}+1\right)},
$$

where

$$
\begin{aligned}
V_{c} & =\text { cathode volume } \\
C & =\text { normality of } \mathrm{CuSO}_{4} \text { solution }=0.923 \\
N_{1}, N_{2}= & \text { mole percent of }{ }^{63} \mathrm{Cu} \text { and }{ }^{65} \mathrm{Cu} \text { in } \\
& \text { ordinary copper } \\
t & =\text { time in hours. }
\end{aligned}
$$


TABLE 4. Isotope ratios from mass spectrometer analyses and separation coefficient $(\epsilon-1)$ for electromigration

$R_{0}$ and $R_{t}$ represent ratios ${ }^{63} \mathrm{Cu} /{ }^{65} \mathrm{Cu}$ for normal copper and copper sulfate from the cathode compartment after time $t$

\begin{tabular}{|c|c|c|c|c|c|c|}
\hline Experiment & $\begin{array}{c}\text { Anal- } \\
\text { ysis } \\
\text { series }\end{array}$ & $R_{0}$ & $R_{t}$ & $R_{t} / R_{0}$ & $\underset{10^{3}}{(\epsilon-1) \mathrm{x}}$ & $\begin{array}{c}(\epsilon-1) \mathrm{x} \\
10^{3} \text { (aver- } \\
\text { ages) }\end{array}$ \\
\hline $1 \ldots$ & $\begin{array}{l}\mathrm{B} \\
\mathrm{D}\end{array}$ & $\begin{array}{r}\text { a2. } 2087 \\
2.2231\end{array}$ & $\begin{array}{l}\text { 2. } 2499 \\
\text { 2. } 2580\end{array}$ & $\begin{array}{l}1.0187 \\
1.0172\end{array}$ & $\begin{array}{r}0.287 \\
.259\end{array}$ & 0.273 \\
\hline $2 \ldots$ & $\begin{array}{l}\text { A } \\
\text { B } \\
\text { C }\end{array}$ & $\begin{array}{r}2.2454 \\
\text { a2. } 2087 \\
\text { a2. } 2079\end{array}$ & $\begin{array}{l}\text { 2. } 2694 \\
\text { 2. } 2408 \\
\text { 2. } 2439\end{array}$ & $\begin{array}{l}\text { 1. } 0107 \\
\text { 1. } 0145 \\
1.0163\end{array}$ & $\begin{array}{l}.185 \\
.317 \\
.281\end{array}$ & .291 \\
\hline 3. & $\begin{array}{l}\mathrm{A} \\
\mathrm{B} \\
\mathrm{C}\end{array}$ & $\begin{array}{l}\text { 2. } 2371 \\
\text { 2. } 2100 \\
\text { 2. } 2045\end{array}$ & $\begin{array}{l}\text { 2. } 2523 \\
\text { 2. } 2297 \\
\text { 2. } 2276\end{array}$ & $\begin{array}{l}1.0068 \\
1.0089 \\
1.0105\end{array}$ & $\begin{array}{l}.184 \\
.242 \\
.283\end{array}$ & .236 \\
\hline $4 \ldots$ & $\mid \begin{array}{l}\mathrm{A} \\
\mathrm{B} \\
\mathrm{C}\end{array}$ & $\begin{array}{l}\text { 2. } 2371 \\
\text { 2. } 2100 \\
\text { 2. } 2045\end{array}$ & $\begin{array}{l}\text { 2. } 2715 \\
\text { 2. } 2352 \\
\text { 2. } 2408\end{array}$ & $\begin{array}{l}1.0154 \\
1.0114 \\
1.0165\end{array}$ & $\begin{array}{l}.334 \\
.222 \\
.320\end{array}$ & .292 \\
\hline $5 \ldots$ & $\mathrm{D}$ & 2. 2331 & 2. 2373 & 1. 0064 & .112 & .112 \\
\hline
\end{tabular}

a $R_{0}$ values marked with an asterisk represent values obtained after the corresponding $R_{t}$ values. In all other cases the $R_{0}$ values represent averages of values obtained before and after the corresponding $R_{t}$ values.

Values of $\epsilon-1$ for the five experiments are shown in the last two columns of table 4 . The values given in the last column represent terminal values for each experiment. Judging from the work on potassium and chlorine, the initial values of $\epsilon-1$ would be about twice as large as the terminal values. In view of the fact that large samples were required for analysis in the mass spectrometer, sampling was reserved to the end of each run. The average of all the $R_{0}$ values given in column 3 of this table is 2.2192 .

A comparison between the terminal $\epsilon-1$ values obtained in the copper work with those obtained in the work on chlorine (see footnote 2) is given in table 5. On averaging the results from five experiments in both cases, we find that the separation coefficient in concentrating ${ }^{35} \mathrm{Cl}^{-}$is three times as great as that in concentrating ${ }^{63} \mathrm{Cu}^{++}$.
TABLE 5. Comparison between the separation coefficients in the concentration of ${ }^{35} \mathrm{Cl}$ and ${ }^{63} \mathrm{Cu}$

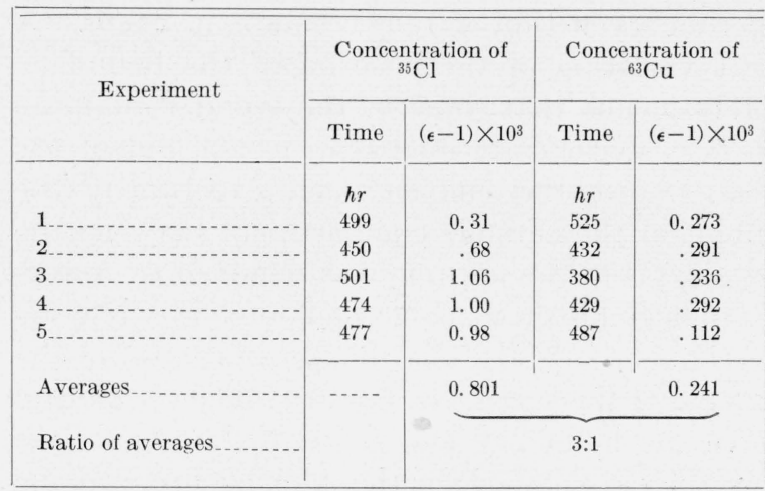

\section{Conclusions}

The results indicate a definite, though small, separation of copper isotopes by the countercurrent electromigration method. The low separation coefficient obtained for copper as compared with chlorine, may be accounted for by the smaller difference in the molecular weight of the two isotopes per unit mass of the copper atom. The fact that the copper ion can exist in aqueous solution in two stages of oxidation, cuprous, $\mathrm{Cu}^{+}$, and cupric, $\mathrm{Cu}^{++}$, may also have something to do with the low separation coefficient. However, other ions that can exist in more than one state of oxidation should be tried before a definite conclusion can be reached in regard to this question.

The authors express their indebtedness to $J$. R. White and A. E. Cameron for the mass-spectrometer analyses reported in this paper.

Washington, March 18, 1948. 